\title{
Effects of Reflective Inquiry Instructional Technique on Students' Achievement and Interest in Radio Television and Electronics Works in Technical Colleges
}

\author{
Dr (Mrs) T. C. Ogbuanya ${ }^{1}$, Dr Ayanda Samuel Owodunni ${ }^{2}$ \\ ${ }^{I}$ Department of Vocational Teacher Education University of Nigeria, Nsukka \\ ${ }^{2}$ Department of Industrial and Technology Education Federal University of Technology, Minna Niger State
}

\begin{abstract}
The study investigated the effect of reflective inquiry instructional technique on students' achievement and interest in Radio Television and Electronic Works trade (RTVE) in technical colleges in Lagos State of Nigeria using quasi experimental pretest posttest non-equivalent research design. The population for the study consisted of 105 year II technical RTVE students. Four research questions were raised and answered while six hypotheses were formulated and tested at 0.05 level of significance. The instruments used for data collection were RTVE Achievement Test (RTVEAT) and RTVE interest inventory (RTVEII). The instruments were validated by three experts in RTVE and measurement and evaluation. The reliability coefficient of RTVEAT was found to be 0.83 using Pearson Product Moment Correlation coefficient, while that of RTVEII was found to be 0.88 using Cronbach Alpha after trial testing. Mean was used to answer the research questions; while ANCOVA was employed to test the hypotheses. Findings from the study revealed that reflective inquiry instructional technique is more effective in improving students' achievement and interest in RTVE than conventional method. There was an effect of gender on students' achievement and interest in RTVE favouring boys. The study found out that there were no interaction effects of reflective inquiry instructional technique and gender on achievement and interest of students in RTVE. It was therefore recommended that the National Board for Technical Education should carry out a review of RTVE trade curriculum for Technical Colleges with a view to incorporate reflective inquiry instructional technique into the teaching of RTVE trade.
\end{abstract}

Keywords: Achievement, Gender, Interest, Radio Television and Electronics works trade and Reflective Inquiry Instructional Technique

\section{INTRODUCTION}

The need to equip students of Radio Television and Electronic Works (RTVE) with the $21^{\text {st }}$ century workplace basic and thinking skills that will enable them adapt to the technological changes and development in the industries required a change from instructional approaches that are teacher centered, which are based on behavioural learning theories to those that are students-centered, which are based on cognitive psychological learning theories for which reflective inquiry instructional techniques is one (Ogwo 2005).

Agboola and Oloyede (2007) defined inquiry as a term used in science and other related fields that refers to a way of questioning, seeking knowledge or information or finding out about phenomena. They also explained that it involves investigation, searching, and doing, formulating hypotheses, gathering and interpreting data and arriving at a conclusion. In inquiry situation, students learn not only concepts and principles but selfdirection, responsibility and social communication. Garrison (2000) stressed that for inquiry to have some practical value in school environment with its multidiscipline nature and developmental level, it must be viewed as an overarching concept and method.

Critical thinking which involves reflective thinking according to Garrison, (2000) has its genesis in the work of John Dewey and method of scientific inquiry. Critical thinking is seen as the means to personal meaning, reconstruction of knowledge and an educated person. To think critically or reflectively is to make sense of things through questioning, debate and confirming understands collaboratively. Critical thinking integrated the reflective and share activities of community of inquiry. Thus inquiry and reflective thought (critical thinking) combined together to form reflective inquiry.

Previous research on reflective thinking suggests that three areas are particularly important in prompting reflective thinking, although various elements can do so. First, particular teaching method can influence the development of students' reflective thinking skills. Scaffolding tools such as interactive journal, conceptual graphic organizer, question prompts tacit and concept map also prompt reflective thinking; use of wait time by teacher and finally, the learning environment may prompt students to make their own decisions regarding their learning progress (Williams, 1996, Kinchin \& Hay, 20000, Rowe, 1974 cited in Hae-Deck, Tiffany \& Barbara, 2006). 
Reflective inquiry therefore, is a thinking process through which individuals examine their experiences to better understand the assumptions and implications of events and actions in their lives through a close examination for information or truth (Wallace, 1996,). In RTVE classroom where journals on applications of electronic emission are presented, the students can reflect on the contents of the journals, bring out meaning from the journals and construct their own understanding. This will enable the students to identify electronic emission devices and their functions. Wallace (1996) maintained that the process of reflective inquiry entails asking penetrating questions, challenging assumptions and carefully examining the implications of their actions and choices. Boyd (1992) found that continuous "critical" inquiry is a common trait of schools that are successful in maintaining improvement efforts. Hae-Deck, Tiffany \& Barbara (2006) notes that reflective inquiry can not only force conversations (oral discussion) among students about what is important, but also help create a shared sense of purpose and collaborative work among students.

Critical thinking skills are higher order skills involving the synthesis of information and thought. The use of thinking skills instructional strategy encourages creative thinking which makes students build upon previous learning to construct new knowledge and become effective problem solvers. Thinking skills according to Cotton as cited in Owoso (2009) is a set of basic and advanced skills and sub-skills that govern a person's mental process. Cotton explained that these skills consist of knowledge, disposition, cognitive and metacognitive operation. In a reflective inquiry classroom, Schauble (1993) noted that developing thinking skills in the students requires the use problem solving approach to introduce students to the thought processes necessary to arrive at a solution. These thought processes include identifying the problem, gathering information about the problem, generating potential solutions to the problem and developing and testing the optimal solution to the problem.

Furthermore, the introduction of reflective inquiry which is based on cognitive theory of learning according to Dewey (1933) involves the process of mentally engaging in cognitive process to understand conflicting factors in a situation. The challenge of facilitating reflective inquiry is dependent upon knowledge expertise and metacognitve appreciation of inquiry methods and thinking processes associated with the subject area. For this reason, it is essential for teachers to model thinking and comprehension processes in an explicit manner. In this way, students can see knowledge experts engaged in reflective inquiry which contextualizes the use of both domain specific strategies and metacognitive control strategies (Kintsch, 1993).

The use of reflective inquiry in vocational and technical education can make significant contributions by providing appropriate learning opportunities to diverse learners and motivating students to learn vocational and technical subjects, both inside and outside the school environment. Reflective inquiry present students with problems and allow students to utilize the inquiry as a powerful tool to carry out investigation and to solve problems. Educational inquiry is designed both to teach content and to enhance thinking and higher-order problem solving skills for academic achievement and for work place (Kinchin and Hay, 2000 cited in Hae-Deck, Tiffany \& Barbara, 2006).

Therefore, the development of work place thinking and problem solving skills in the students for $21^{\text {st }}$ century workplace as suggested by UNESCO and ILO (2002) emphasized that there should be adjustment in the programmes of educational institutions. In the same vein, Ogwo \& Oranu (2006) explained that the adjustment will affect the curricular implementation processes which are executed through learning experiences and content. They stressed further that these adjustments by the educational institutions would largely be pivoted on the instructional activities employed.

Despite the needs for adjustment, lecture method and demonstration method which are based on behavioural learning theories are still the main teaching/learning strategies employed for implementing the curriculum in the technical colleges. According to Oranu (2003) lecture and demonstration methods which are predominantly used in teaching RTVE are content driven and certainly not learner-centered. Students are not given enough opportunities to participate in the class activities. These methods of teaching may also account for poor performance of vocational education students at public examinations (Aina 2000) and at the work place when employed on graduation (Fawcet, 1998).

The influence of technological development in the industries has also rendered traditional skills possessed by the graduates of vocational and technical institutions inadequate for work in the industries while creating the need for new and often sophisticated skill. Obviously, the industries need the service of Radio, Television and Electronic Works (RTVE) craftsmen and technologists who can adapt to the technological changes and advancement in the industries

RTVE is one of Electrical/Electronic trades offered in Nigerian technical colleges (Federal Republic of Nigeria, 2004). The programmes in technical colleges are offered at levels leading to the award of National Technical Certificate (NTC) and Advanced National Technical Certificate (ANTC) for craftsmen and master craftsmen respectively (Federal Government of Nigeria, 2000). The Federal Government of Nigeria (FRN, 2004) pointed out that the main feature of the curricular activities for technical colleges shall be structured in foundation and trade modules, the curriculum for each trade shall consist of general education, theory and 
related courses, workshop practice, industrial training components and small business management and entrepreneurial training. However, despite the huge investment by successive Nigerian governments on technical colleges aimed at improving their programme and student's performance, the academic achievement of RTVE students in both internal and external examination is not encouraging.

Academic achievement connotes performance in school subject as symbolized by a score on an achievement test. Epunnah (1999) defined performance as the learning outcome of students which include the knowledge, skills and ideas acquired and retained through their course of studies within and outside the classroom situation. Academic achievement in RTVE is the quality and level of skills acquired and retained by students. Mbah (2002) remarked that achievement is dependent upon several factors among which are instructional techniques, the learning environment, motivation for stimulating students' interest in learning and the learners. Therefore, the academic achievement of students in RTVE also depends on the interest of the students in the subject.

Interest involves a sense of concern with and curiosity about something, for instance, students having an interest in technology subjects. Works (1999) defined interest as a social construction developing within the dynamic relationship between the individual and the situation. Students' interest in learning are associated with students' anxiety to learn. Interest is fundamental in any individual's choice task. It consists of feelings and tendencies towards concrete matter. A characteristic feature of interest is a manifestation of a different preference toward actions, events or plans. A student's interest in academic achievement will induce him to behave and act in a certain way towards his studies. Therefore, the use of reflective inquiry instructional technique is important to provide rich environment that will stimulate the interest of technical college students in technological subjects such as RTVE.

Gender has been identified as one of the factors influencing student's interest and achievement in vocational and technical education (Howden, 1998). There has been a renewed debate on the controversial issue of gender differences on science and technology achievement and interest. This debate currently focuses on why women are not interested in seeking careers in technology occupations. The most comprehensive reviews of the research in the area of gender differences have shown very few true differences between math and verbal abilities between men and women (Halpern, 2000). Other research has also shown a decline in the differences between the genders in the past few decades on vocational courses, suggesting that the more exposure that women are getting to vocational and technical classes. Even though this research puts into questions whether gender differences still exist in academic achievement and interest, many researchers are still finding differences in performance as well as general abilities in areas related to vocational and technical. This study made an attempt to find out if reflective inquiry instructional technique has a significant effect on academic achievement and interest of male and female students in RTVE. Therefore the study was designed to determine the effect of reflective inquiry instructional techniques on students' academic achievement and interest in RTVE in the technical colleges.

\subsection{Statement of the Problem}

In spite of the huge investment by successive Nigerian governments on technical colleges programme aimed at improving the image and performance of technical college students, the performance of the students in Radio, Television and Electronics Works (RTVE) trade has never been encouraging in Lagos state specifically. NABTEB results show that average failure rate in RTVE trade in the years 2005, 2006, 2007and 2008 were $56 \%, 67 \%, 48 \%$ and $73 \%$ respectively (NABTEB, 2010). The Federal Ministry of Education (FGN, 2000) has observed that some of the factors responsible for the high failure rate of technical college students in the NABTEB examinations particularly in the main trades include poor quality of teaching staff and poor teaching in the Technical Colleges. Moreover, it has been discovered that the persistent poor academic achievement and low interest of students in RTVE and other technical subjects is as a result of the inappropriate teaching methods (that do not incorporate proper techniques) adopted by teachers (Aina, 2000), especially adoption of teachercentered methods.

Obviously, the adoption of only teacher-centered methods of teaching by the teacher results into ineffective use of varieties of instructional method and instructional facilities and inability of teachers to effectively implement the curriculum to naturally increase students' interest, involvement and commitment in learning. The shortcoming in this teacher-centered method of teaching could be responsible for poor performance of RTVE students in public examinations (NABTEB 2002). Hence, the problem of this study is: can reflective inquiry instructional technique produce significant effect on the academic achievement and interest of RTVE students in technical colleges? 


\subsection{Purpose of the Study}

The study sought to:

1. Determine the effect of reflective inquiry instructional techniques on students' academic achievement in RTVE.

2. Determine the influence of gender on academic achievement of students studying RTVE.

3. Determine the effect of reflective inquiry instructional techniques on students' interest in studying RTVE.

4. Determine the influence of gender on student's interest in studying RTVE.

\subsection{Research Questions}

The following research questions guided the study;

1. What is the effect of reflective inquiry instructional technique on students' mean achievement scores in RTVE?

2. What is the effect of reflective inquiry instructional technique on students' mean interest scores in studying RTVE?

3. What is the influence of gender on students mean achievement scores in RTVE?

4. What is the influence of gender on students' mean interest scores in RTVE?

\subsection{Hypotheses}

The following null hypotheses which were tested at .05 level of significance guided this study: .

$\mathrm{HO}_{1}$ : There is no significant difference in the mean achievement scores of students taught RTVE with reflective inquiry instructional techniques and those taught with conventional method.

$\mathrm{HO}_{2}$ : There is no significant difference between the effect of gender (male and female) on students achievement in RTVE.

$\mathrm{HO}_{3}$ : There is no significant interaction effect of treatments given to students and their gender with respect to their mean scores on the RTVE Achievement test.

$\mathrm{HO}_{4}$ : There is no significant difference in the mean interest scores of students taught RTVE with reflective inquiry instructional techniques and those taught with conventional method.

$\mathrm{HO}_{5}$ : There is no significant mean difference between the effect of gender (male and female) on students interest in RTVE.

$\mathrm{HO}_{6}$ : There is no significant interaction effect of treatments given to students and their gender with respect to their mean scores on RTVE interest inventory.

\section{RESEARCH METHODS}

\subsection{Design of the Study}

The design of the study was quasi-experimental research design. The research makes use of pre-test, post-test non-equivalent control group design. The researcher randomly assigned intact classes to treatment and control groups. This was necessary in order not to disrupt the normal classes of the students and the school timetable.

The design is symbolically represented as follows:

$$
\begin{array}{r}
\mathrm{E}_{\mathrm{G}}, \mathrm{O}_{1} \times \mathrm{O}_{1} \\
\mathrm{C}_{\mathrm{G}} \mathrm{O}_{1}-\mathrm{O}_{1}
\end{array}
$$

Where $\mathrm{E}_{\mathrm{G}}$ stands for experiment group

$\mathrm{C}_{\mathrm{G}}$ stands for control group

$\mathrm{O}_{1}$ stand for pre-test/post-test observation

$\mathbf{X}$ stand for the treatments using Reflective Instructional Technique

- stand for the use of the Conventional method

\subsection{Population of the Study}

The population of this study comprises 105 ( 76 boys and 29 girls) year II students of RTVE in all the technical colleges that offer RTVE in Lagos state. The entire population was used for the study

\subsection{Instrument for Data Collection}

The instrument for data collection for this study consists of RTVE achievement test (RTVEAT) and RTVE interest inventory (RTVEII). The RTVEAT which was used to test the achievement of students in RTVE was developed based on CRT 12 (Electronic Devices and Circuits) module in the curriculum. It consists of $30-$ multiple choice items with five options. The RTVE interest inventory (RTVEII) was also developed by the researcher. The items of the interest inventory were based on four point scales of Strongly Agreed (SA), Agreed (A), Disagreed (D) and Strongly Disagreed (SD). 
The RTVE achievement test (RTVEAT) and RTVE interest inventory (RTVEII) items were subjected to face and content validation by three Lecturers in RTVE and measurement and evaluation.

The pilot tryout of RTVEAT and RTVEII were conducted using equivalent sample of Technical II RTVE students in Federal Science and Technical College Ijebu-Mushin, Ogun State and the psychometric test analysis was carried out to determine the Difficulty and Discrimination Index of each item in the test. An item is good if it has Difficulty Index ranging from 20 to 80; Discrimination of 0.20 and above and its entire distractor index a negative decimal (Okoro, 1999). Therefore, a total of the 30 items of the RTVEAT had good difficulty, discrimination and distractor indices. The reliability coefficient of the RTVEAT was found to be .83 using Kuder Richardson formula 20 (K - R 20), while the reliability coefficient computed for the RTVE Interest inventory was found to be 0.88 using Cronbach Alpha.

\subsection{Lesson Plan}

The researcher prepared two (2) sets of lesson plans for the teaching of the module set out for the study. These lesson plans were prepared from the units in the test blue print. Each set contains ten (10) lesson plans that lasted for a period of ten weeks at 90 minutes duration. One set of the lesson plan was written based on reflective instructional strategies, the subject teacher in the experimental group applied this lesson plan at different stages of instructional process, while the second set was prepared based on conventional approach in teaching RTVE and was used by the teacher in control group. Three experienced RTVE and methodology experts from University of Nigeria Nsukka also validated the two sets of lesson plans

\subsection{Experimental Procedure}

The conduct of the study took place during the normal school lesson periods. The normal time table of the schools used for the study was followed. The regular school RTVE teachers were used. The schools that were given the treatment, that is, Reflective Inquiry strategy served as experimental group, while the school that the conventional lesson plan was used in teaching the students served as the control group.

On the first day, before the lesson commences, the RTVEAT and RTVEII pretest were administered to both the experimental and control groups after which proper teaching commenced by using the prepared lesson plans. The teacher for each group was supervised by the researcher during the teaching process to be sure they did not deviate from the prepared lesson procedure. Each lesson lasted for 90 minutes and the treatment lasted for 10 weeks. At the end of the treatment, a posttest was administered on both groups with the RTVEAT and RTVEII; the scores obtained from both groups were compared to determine if there is any significant difference in the performance of the two groups. The data collected was used for further analysis; therefore they were collected and kept under the custody of the researcher.

\subsection{Method of Data Analysis}

Data collected for this study were analyzed as follows; mean was used to answer all the research questions. The null hypotheses were tested using Analysis of Covariance (ANCOVA) at 0.05 level of significance. The major assumptions of ANCOVA include.

\section{RESULTS}

The results were presented according to the research questions and null hypotheses that guided the study.

\subsection{Research Question 1}

What is the effect of reflective inquiry instructional techniques on student's academic achievement in RTVE?

Table 1 Mean of Pretest and Posttest Scores of Experimental and Control Groups in the Academic Achievement

\begin{tabular}{lcccc}
\hline \multicolumn{1}{c}{ Group } & $\mathbf{N}$ & Pretest & Posttest & \multirow{2}{*}{ Mean Gain } \\
\cline { 3 - 5 } & & $\overline{\mathrm{X}}$ & $\overline{\mathrm{X}}$ & 20.47 \\
\hline Experimental & 43 & 4.41 & 24.88 & 14.48 \\
\hline Control & 62 & 4.27 & 18.75 & \\
\hline
\end{tabular}

The data presented in Table 1 show that the experimental group had a mean score of 4.41 in the pretest and a mean score of 24.88 in the posttest making a pretest, posttest mean gain in experimental group to be 20.47. The control group had a mean score of 4.27 in the pretest and a posttest mean of 18.75 with a pretest, posttest mean gain of 14.48. With this result, the students in the experimental group performed better in the 
achievement test than the students in the control group. Hence, reflective inquiry instructional techniques is effective than the conventional teaching method on students achievement in RTVE

\subsection{Research Question 2}

What is the effect of gender on academic achievement of students studying RTVE?

Table 2 Mean of Pretest and Posttest of Male and Female Students Taught RTVE in the Achievement Test

\begin{tabular}{|c|c|c|c|c|c|c|c|c|}
\hline \multirow[b]{2}{*}{ Gender } & \multicolumn{4}{|c|}{ Reflective Inquiry Techniques } & \multicolumn{4}{|c|}{ Conventional Method } \\
\hline & $\mathrm{n}$ & Pretest & Posttest & $\begin{array}{c}\text { Mean } \\
\text { Gain } \\
\bar{X}\end{array}$ & $\mathrm{n}$ & Pretest & Posttest & $\begin{array}{c}\text { Mean } \\
\text { Gain } \\
\overline{\mathrm{X}}\end{array}$ \\
\hline Male & 32 & 4.37 & 25.03 & 20.66 & 44 & 4.25 & 19.22 & 14.97 \\
\hline Female & 11 & 4.54 & 24.45 & 19.91 & 18 & 4.33 & 17.61 & 13.28 \\
\hline
\end{tabular}

The data presented in Table 2 show that male students taught RTVE with reflective inquiry technique had a mean score of 4.37 in the pretest and a mean score of 25.03 in the posttest making a pretest, posttest mean gain in the male students taught with reflective inquiry techniques to be 20.66. Meanwhile, female students taught RTVE with reflective inquiry technique had a mean score of 4.54 in the pretest and a posttest mean of 24.45 with a pretest, posttest mean gain of 19.91 . Also, male students taught with conventional method had a mean score of 4.25 in the pretest and a mean score of 19.22 in the posttest making a pretest, posttest mean gain in the male students taught with conventional method to be 14.97 Meanwhile, female students taught RTVE with conventional method had a mean score of 4.33 in the pretest and a posttest mean of 17.61 with a pretest, posttest mean gain of 13.28. With these results male students taught RTVE had higher mean scores than female students in the Achievement Test. Thus, there is an effect attributable to gender on the achievement of students taught RTVE.

3.3 Research Question 3

What is the effect of reflective inquiry instructional techniques on student's interest in studying RTVE?

Table 3 Mean of Pretest and Posttest Scores of Experimental and Control_Groups in the interest inventory

\begin{tabular}{llccc}
\hline \multicolumn{1}{c}{ Group } & $\mathbf{N}$ & Pre-test & Post-test & \\
\cline { 2 - 4 } & & $\overline{\mathrm{X}}$ & $\overline{\mathrm{X}}$ & Mean Gain \\
\hline Experimental & 43 & 124.79 & 145.05 & 20.26 \\
Control & 62 & 124.10 & 139.58 & 15.48 \\
\hline
\end{tabular}

Table 3 shows that the experimental group had a mean score of 124.79 in the pretest and a mean score of 145.05 in the posttest making a pretest, posttest mean gain in experimental group to be 20.26. The control group had a mean score of 124.10 in the pretest and a posttest mean of 139.58 with a pretest, posttest mean gain of 15.48. With this result, the experimental group interest is higher than the interest of the students in the control group. Therefore, reflective inquiry instructional techniques is effective and even effective than the conventional teaching method in stimulating students' interest in RTVE

\subsection{Research Question 4}

What is the effect of gender on students' interest in studying RTVE?

Table 4 Mean of Pretest and Posttest of Male and Female Students Taught RTVE in the interest inventory

\begin{tabular}{|c|c|c|c|c|c|c|c|c|}
\hline \multirow[b]{2}{*}{ Gender } & \multicolumn{4}{|c|}{ Reflective Inquiry Techniques } & \multicolumn{4}{|c|}{ Conventional Method } \\
\hline & $\mathrm{N}$ & Pretest & Posttest & $\begin{array}{c}\text { Mean } \\
\text { Gain } \\
\bar{X}\end{array}$ & $\mathrm{n}$ & Pretest & Posttest & $\begin{array}{c}\text { Mean } \\
\text { Gain } \\
\bar{X}\end{array}$ \\
\hline Male & 32 & 124.62 & 144.97 & 20.35 & 44 & 124.18 & 139.97 & 15.79 \\
\hline Female & 11 & 125.27 & 145.27 & 20.00 & 18 & 123.89 & 139.17 & 15.28 \\
\hline
\end{tabular}

Table 4 shows that male students taught RTVE with reflective inquiry technique had a mean score of 124.62 in the pretest and a mean score of 144.97 in the posttest making a pretest, posttest mean gain in the male students taught with reflective inquiry techniques to be 20.35. Female students taught RTVE with reflective inquiry technique had a mean score of 125.27 in the pretest and a posttest mean of 145.27 with a pretest, posttest mean gain of 20.00. Male students taught with conventional method had a mean score of 124.18 in the pretest and a mean score of 139.97 in the posttest making a pretest, posttest mean gain in the male students taught with 
conventional method to be 15.79. Meanwhile, female students taught RTVE with conventional method had a mean score of 123.89 in the pretest and a posttest mean of 139.17 with a pretest, posttest mean gain of 15.28. With these results male students taught RTVE had higher mean scores than female students in the interest inventory. Thus, there is an effect attributable to gender on the interest of students taught RTVE.

\subsection{Hypotheses}

$\mathrm{HO}_{1}$ : There is no significant difference in the mean achievement scores of students taught RTVE with reflective inquiry instructional techniques and those taught with conventional method

$\mathrm{HO}_{2}$ : There is no significant mean difference between the effect of gender (male and female) on students' achievement in RTVE

$\mathrm{HO}_{3}$ : There is no significant interaction effect of treatments given to students and their gender with respect to their mean scores on the RTVE Achievement Test

Table 5 Summary of Analysis of Covariance (ANCOVA) for Test of Significance between the Mean Scores of Experimental and Control groups in the Achievement Test, Effects of Gender and Interaction Effect of

Treatments given to Students and their gender with respect to their mean scores on the RTVE Achievement Test

\begin{tabular}{lrrrrr}
\hline Source & Sum of Squares & Df Mean Square & F & \multicolumn{1}{l}{ Sig. } \\
\hline Corrected Model & $992.311^{\mathrm{a}}$ & 4 & 248.078 & 47.871 & .000 \\
Intercept & 1706.006 & 1 & 1706.006 & 329.203 & .000 \\
Pretest & 3.478 & 1 & 3.478 & .671 & .415 \\
Group & 783.680 & 1 & 783.680 & $151.225^{*}$ & .000 \\
Gender & 25.059 & 1 & 25.059 & $4.835^{*}$ & .030 \\
Group * Gender & 5.202 & 1 & 5.202 & 1.004 & .319 \\
Error & 518.223 & 100 & 5.182 & & \\
Total & 4899.000 & 105 & & & \\
Corrected Total & 1510.533 & 104 & & & \\
\hline
\end{tabular}

*Significant at sig of $\mathbf{F}<.05$

The data presented in Table 5 shows F-calculated values for mean scores of experimental and control groups in the achievement test, gender and interaction effect of treatments and gender on students' achievement in RTVE. The F-calculated value for Group is 151.225 with a significance of $F$ at .000 which is less than .05 . The null-hypothesis is therefore rejected at .05 level of significance. With this result, there is a significant difference between the mean achievement scores of students taught RTVE with reflective inquiry instructional techniques and those taught with conventional method. The F-calculated value for gender is 4.835 with a significance of $\mathrm{F}$ at .030 which is less than .05 . This means that there is significant difference between the effects of Gender on students' achievement in RTVE. Therefore, the null hypothesis of no significant difference between the effect of gender (male and female) on students' achievement in RTVE is rejected at .05 level of significance. The interaction of treatments and gender has F-calculated value of 1.004 with significance of $F$ of .319. Since .319 is higher than .05 , the null hypothesis for interaction effect of treatment and gender is accepted. Hence, there is no significant interaction effect of treatments given to students and their gender with respect to their mean scores on the RTVE Achievement Test.

$\mathrm{HO}_{4}$ : There is no significant difference in the mean interest scores of students taught RTVE with reflective inquiry instructional techniques and those taught with conventional method

$\mathrm{HO}_{5}$ : There is no significant mean difference between the effect of gender (male and female) on students' Interest in RTVE

$\mathrm{HO}_{6:} \quad$ There is no significant interaction effect of treatments given to students and their gender with respect to their mean scores on the RTVE interest inventory

Table 6 Summary of Analysis of Covariance (ANCOVA) for Test of Significance between the Mean Scores of Experimental and Control groups in the Interest Inventory, Effects of Gender and Interaction Effect of

Treatments given to Students and their gender with respect to their mean scores on the RTVE Interest Inventory

\begin{tabular}{lrrrrr}
\hline Source & Sum of Squares & Df Mean Square & \multicolumn{1}{c}{ F } & \multicolumn{1}{c}{ Sig. } \\
\hline Corrected Model & $778.010^{\mathrm{a}}$ & 4 & 194.503 & 17.786 & .000 \\
Intercept & 96.661 & 1 & 96.661 & 8.839 & .004
\end{tabular}




\begin{tabular}{lrrrrr} 
Pretest & 14.349 & 1 & 14.349 & 1.312 & .255 \\
Group & 515.452 & 1 & 515.452 & $47.136^{*}$ & .000 \\
Gender & .764 & 1 & .764 & .070 & .792 \\
Group * Gender & 1.675 & 1 & 1.675 & .153 & .696 \\
Error & 1093.552 & 100 & 10.936 & & \\
Total & 2113699.000 & 105 & & & \\
Corrected Total & 1871.562 & 104 & & & \\
\hline
\end{tabular}

*Significant at sig of $\mathbf{F}<.05$

The data presented in Table 5 show F-calculated for mean scores of experimental and control groups in the interest inventory, gender and interaction of treatment and gender on students' interest in RTVE. The Fcalculated value for group is 47.136 with a significance of $F$ at .000 which is less than .05 . Hence, the nullhypothesis is therefore rejected at .05 level of significance. The F-calculated for gender stood at .070 with a significance of $\mathrm{F}$ at .792 which is greater than .05 . The null-hypothesis is therefore accepted at .05 level of significance. With this result there is no significant difference between the effect of gender (male and female) on students' interest in RTVE. The interaction effect of treatment and gender has F-calculated value of .153 with significance of $\mathrm{F}$ of .696 which is greater than .05 . This result means that there is no significant interaction effect of treatments given to students taught RTVE and their gender with respect to their mean scores on RTVE Interest Inventory

$\mathrm{HO}_{4}$ : There is no significant mean difference in the achievement scores of high level ability students and low level ability students taught RTVE with reflective inquiry instructional techniques

\subsection{Discussion of the findings}

The data presented in Table 1 provided answer to research question one, finding revealed that main effect of reflective inquiry instructional technique on students achievement in RTVE is higher the main effect of conventional technique. At the same time, Analysis of covariance was used to test the first hypothesis, Table 5, at the calculated F-value (151.225), Significance of F (.000) and confidence level of .05 there was a statistically significant difference between the main effect of (reflective inquiry techniques and conventional method) on students achievement in RTVE confirming that the difference between the main effect of reflective inquiry instructional technique and conventional method was statistically significant. The implication of this finding is that reflective inquiry instructional technique (thinking skills, concept mapping, scaffolding graphic organizers, question prompt tacit, interactive journals) is more effective than conventional method in enhancing students' achievement in RTVE The findings that reflective inquiry instructional technique has positive effect on students achievement is similar to the finding of Hae-Deck, Tiffany \& Barbara (2006) that discovered that reflective teaching methods prompts students to thinking effectively. A possible explanation for the effectiveness of the reflective inquiry instructional techniques is the students' active involvement in learning process using cooperative learning and interactive journal strategies through frequent verbalization in both extensive and intensive way, clarifying, probing, questioning and the 'eye to eye', 'knee-to-knee' communication posturing as the students interacts in groups with the journals. This also affirms Tochonites (2000) and Bonwel and Elson's (2003) views that active learning approach facilitate active knowledge construction, develops higher order thinking skills, improves memory and enhance transfer of learning to other situation. Von Glasersfield (2001) was of the opinion that by teaching students to think, they will gradually begin to realize that conscious reflection secretes understanding. He maintained that when students learn to think, they will be able to tackle all sort of new problem creatively and will have acquired some confidence

In learning, providing opportunities to interact with course material through the use of interactive journals tends to change the course from teacher-centred approach to one that is more student-centred, and focused on the cognitive development and construction of knowledge in the students (Dewey, 1933). Hence, one means of constructing knowledge is to create meaning by doing and interacting. Creating support for knowledge construction within the students is a critical component to the success of developing self-motivated, intellectually stimulated learners.

The data presented in Table 2 provided answer to research question 2. Finding revealed that male students had a higher mean score in the RTVE achievement test than female students. At the same time, Analysis of covariance was employed to test the second hypothesis, Table 5, at the calculated F- value (4.835), significance of $\mathrm{F}(.030)$ and confidence level of .05 , there was a significant difference between the main effects of gender (male and female) on students' achievement in RTVE which confirmed that the difference between the achievement of male and female students in RTVE was statistically significant favouring boys. The obvious implication of this finding is that there was an effect attributable to gender on achievement of students in RTVE. 
This finding is similar to findings of several other studies that had been conducted on gender effects on achievement of male and female students in sciences and other fields. For instances, one of the important discoveries emerging from studies involving the effect of inquiry based instructional approach on academic achievement was the revelation of gender differences favouring boys. This also affirms Ebeh (2000), Aiyedun (2000) and Mba, (2002) opinion that it has been documented that disparity exists between male and female students' performance in sciences and other related fields, and in some cases boys had an edge over girls in academic achievement. Generally, boys were consistently found to perform better than girls on vocational and technical achievement tests suggesting that boys generally possess greater vocational and technical skills than girls (Owoso, 2010). Thus, in studies where differences in achievement were evident males typically had stronger vocational and technical skills than girls. The identified gender effect on achievement in RTVE was responsible for the significant gender effect found on students' achievement in RTVE. Thus, the superiority of male in vocational skills had responsible for their improved achievement in RTVE. However, Analysis of covariance was used to test hypothesis three, Table 5. At the calculated F-value (1.004), significance of F (.319) and confidence level of .05, there was no interaction effect of treatment given to students and their gender with respect to their mean scores on RTVE Achievement test.

The data presented in Table 3 provided answer to research question 3. Finding revealed that mean scores of reflective inquiry technique on students' interest in RTVE is higher than the mean scores of conventional method. Analysis of covariance presented in Table 6 confirmed that the difference between the main effects of (reflective inquiry instructional Technique and conventional method) in students' interest inventory was significant. The significant difference is attributed to the treatment given to the treatment groups assigned to reflective inquiry instructional technique. This finding indicates that reflective inquiry instructional technique is more effective in stimulating students' interest in RTVE than the conventional method. Onyekwerre (2001) asserted that the degree of understanding by students depends on several interacting variables such as learning materials, student's interest, school environment and teaching techniques. He therefore emphasized that teacher should be endeavour to adopt instructional techniques that are capable of stimulating students interest.

Analysis of covariance was used to test hypothesis five, Table 6. At the calculated F-value (47.136), Significance of F (.000) and confidence level of .05, there was significance difference between the mean interest scores of students taught RTVE with reflective inquiry instructional techniques and those taught with conventional method favouring those taught with reflective inquiry instructional techniques. The significant difference is attributed to the treatment given to the treatment groups assigned to reflective inquiry instructional technique.

The data presented in Table 4 provided answer to research question 4. Finding revealed that male students had a higher mean score in the RTVE interest inventory than female students. At the same time, Analysis of covariance was employed to test the fifth hypothesis, Table 6, at the calculated F- value (.070), significance of $F(.792)$ and confidence level of .05 there was a significant difference between the main effects of gender (male and female) on students' interest in RTVE which confirmed that the difference between the mean scores of male and female students in the RTVE interest inventory was statistically significant favouring boys. The obvious implication of this finding is that there was an effect attributable to gender on students' interest in studying RTVE. This affirms Dyankor (1996) views that in many countries in conformity with certain traditions, technical and vocational education is regarded predominantly for boys only and attempt are being made to encourage girls to develop interest in vocational and technical education and also facilitate their attendance in vocational and technical institution. Generally, boys were consistently found to develop interest in vocational education better than girls.

In addition, the analysis of covariance of the treatments effects on interest presented in Table 6 showed that there was no significant difference between the main effects of treatment (reflective inquiry instructional technique) and conventional method on students' interest in RTVE. Furthermore, another salient finding from this study is that analysis of covariance of test of significant difference between the main effects of gender on students' interest in RTVE as presented in Table 6 showed that there was no significant difference between the main effects of gender (male and female) on students' interest in RTVE. This means that the observed difference in the mean interest scores of male and female students was not statistically significant.

\section{CONCLUSIONS}

The need to find the best method to assist Electronics students in learning Radio, Television and Electronics Works (RTVE) Trade and stimulate their interest is paramount since interest is essential for achievement in RTVE and engineering profession as a whole. The study therefore, set out to determine the effect of reflective inquiry instructional technique on academic achievement and interest of RTVE students in Technical Colleges. This study has found out that Reflective inquiry instructional technique is more effective in improving students' achievement and interest in RTVE than Conventional technique. Also the study revealed 
that, there was an effect attributable to gender on students' achievement and interest in RTVE. However, the study found out no interaction effects of Reflective inquiry instructional techniques and gender on achievement and interest of Technical College students in RTVE. This simply means that the effectiveness of Reflective inquiry instructional techniques on students' achievement and interest in RTVE does not depend on the levels of gender. Hence, irrespective of nature of sex, learners will record improved performance in their achievement and interest in RTVE when reflective inquiry instructional technique is employed for teaching RTVE. These results therefore showed that reflective inquiry instructional technique is a viable teaching method for RTVE. It is hoped therefore, that if reflective inquiry instructional technique is taken into consideration in the teaching of RTVE in Technical Colleges, the craftsmen trained will graduate with necessary skills that will enable them to be self employed, gainfully employed in the industries or further their studies in higher institutions. Based on the findings, it was recommended that technical college teachers should adopt the use of reflective inquiry instructional technique to teach RTVE.

\section{RECOMMENDATIONS}

Based on the findings of this study and the subsequent discussion, the following recommendations are made:

1. Technical College teachers should adopt the use of the reflective inquiry instructional technique to the teaching of RTVE.

2. National Board for Technical Education (NBTE) should consider review of curriculum for RTVE with a view to incorporating reflective inquiry instructional technique into the teaching of RTVE

3. Government should provide tools and equipment needed to teach the state- of- the- art of Radio Television and Electronic Works in the Technical Colleges. I

4. Workshops, seminars and conferences should be organized by Ministry of Education and administrators of Technical Colleges to enlighten technical teachers and improve their knowledge and skills on the use of reflective inquiry instructional techniques for improving students' achievement and interest in RTVE.

\section{REFERENCES}

[1] Agboola, O. S. and Oloyede, E. O. Effects of project, inquiry and lecture-demonstration teaching methods on senior secondary students achievement in separation of mixtures practical test. Journal of Educational Research and Review 2(6),2007, 124-132.

[2] Aina, O. Nigeria technical and vocational education in the near future. In Federal Ministry of Education (2001), The National Master-plan for Technical and Vocational Development in Nigeria in the $21^{\text {st }}$ Century with the Blue Print for the Decade 2010. Abuja, FME 2000, 23-32.

[3] Aiyedun, J. O. Influence of sex difference of students in their Achievement in secondary school

[4] mathematics. The journal of the mathematics association of Nigeria (25)91, 2000: 102.

[5] Bonwell, C. C. and Elson, J. A. Active learning: Intelligence. Retrieved on February 20, 2004 from http//:www.dmu.ac.uk/-Jamesa/learningintellig.htm 2003

[6] Boyd, D. Perspectives on instruction. Retrieved on 20/7/2008 from http://edweb.sdu:edu/courses/edutech/html. 1992

[7] Dewey, J. How we think. (Lexington, M.A. Health, 1933).

[8] Dyankov, A. Current trends and issues in vocational and technical education. Retrieved May 12, 2007, from http://www.unesco.org, 1996

[9] Ebeh, C. O. Strategies for increasing female enrolment in mathematics for technological development in the next millennium. ABACUS: Journal of mathematics association of Nigeria 25 (1), 2000, 83-90.

[10] Epunnah, A. D. Influence of School environmental variables on academic performance as perceived by students, University of Nigeria, Nsukka, M.Ed, 1999.

[11] Fawcet, F. Gender issue in technical and vocational education. In Dyankov, A. Current Trends and Issues in Vocational and Technical Education. Retrieved May 12 2007, from http://www.unesco.org,1998

[12] Federal Government of Nigeria. Technical and Vocational Education Development in Nigeria in the $21^{\text {st }}$ century with the blue-print for the Decade 2001-2010: Abuja; Federal Ministry of Education, 2000.

[13] Federal Republic of Nigeria. National Policy on Education. (Lagos: NERDC, 2004)

[14] Garman, N. B. "Reflection the heart of clinical supervision" a modern rationale for professional practice", Journal of curriculum and supervision, fall (1), 2000, 23-41.

[15] Garrison, D.R. Inquiry and Critical Thinking-Reflective Inquiry Learning commons, communities of inquiry. Retrieved on $9^{\text {th }}$ March, 2013 from http://edweb.sdu:edu/courses/edutech/html. 2006.

[16] Hae-Deck, S.; Tiffany, A.K. \& Barbara, G. (2005) Exploring Instructional Design Factors Prompting Reflective Thinking in Young Adolescents: Canadian Journal of Learning and Technology 31(2), 2005, $148-165$

[17] Howden, K. Understanding Basic concepts in vocational and technical education. Retrieved June 10, 2008 from http//:www. autoworld.com, 1998 
[18] Kintsch, E. Principles of instruction from research on human cognition in I.M spector, M.C. Polson \& D.J. Muralda (Eds). Automating instructional design concepts and issues (Eglewood cliff N.E. Educational Technology, London Routeledge, 1993) 23-42

[19] Mbah P.E. Effects of two instructional methods and some moderator variables on Junior secondary school Home Economics students Academic Achievement.University of Benin, PhD, 2002.

[20] Momoh-olle, J. Y. Effects of cognitive preference and advance verbal organizers on the retention of an O’ level physics textual materials. The Nigeria Teacher Today. 5(1\&2), 1997, 26-34

[21] National Business and Technical Examination Board (NABTEB), National business and technical examination board examiners reports. (Benin: NABTEB, 2002)

[22] National Business and Technical Examination Board (NABTEB), (2010). National business and technical examination board examiners reports. (Benin: NABTEB, 2010)

[23] Ogwo B.A. Functionality Vocational Education in Nigeria Public schools. Examining some policy paradigms. In Uzodimma, C.U. (Ed) Functionality of Education in Nigeria: forum for the inter disciplinary Discuss (TAFLD), 2005, 65-69

[24] Ogwo, B. A., and Oranu, R. N. Methodology in informal and nonformal technical/vocational education. (Nsukka: University of Nigeria press, 2006)

[25] Okoro, O. M. Principles and methods in vocational and technical education. (Nsukka: University Trust Publishers, 1999)

[26] Onwuegbu, O. I. Discover teaching. (Enugu: Forth Dimension publishing co. Ltd, 1979)

[27] Onyekwere, P. E. Child Development; Theory and Practice. (Lagos: T-Excel publishers, 2001)

[28] Oranu R. N. Vocational and Technical education in Nigeria. Retrieved on July 18, 2005 from http//:www.Ibec.Unescoorg.2003

[29] Owoso, J. O. Effects of Constructivist Instructional Approach on Achievement and Retention of Automechanics Students In Technical Colleges. University of Nigeria, Nsukka, PhD, 2010.

[30] Schauble, L. Belief revision in children: The role of prior knowledge and strategies for generating evidence. Journal of Experimental child psychology, 49, 1993, 31-57.

[31] Tochonites, O.C. Creating an effective foreign Language classroom. Retrieved on 19/04/2005 from March 6, 2004, from http//:www.wcer.wisc.edu/step/ep301/Fall2000/Tochonites/stu_cen.html, 2000.

[32] UNESCO \& ILO. Technical and vocational education and training for the twenty-first century. Paris: UNESCO, 2002

[33] Wallace, B. Reflective Inquiry and Instruction. Retrieved April 18, 2008 from http://www/proquest.lmf.com/vod6848.kde, 1996

[34] Williams S. The controversy about quantification in social research. An extension of Gagels historical sketch Educational Researcher 12(12), 1999, 9-12.

[35] Works, S. B. Theory of Teaching in Theory and Research in Teaching, Retrieved April 20, 2009 from http://www/prorvest.lmf.com/vod6748.kve.

[36] Von. Glasserfield, E. Radical constructivism and teaching: Prospects, XXXI (2), 2001, 161-173 